\title{
Ecology of mysid shrimps in the Bornholm Basin (central Baltic Sea)
}

\author{
Kristina Barz $\cdot$ Hans-Jürgen Hirche
}

Received: 19 December 2008 / Revised: 19 April 2009 / Accepted: 21 April 2009 / Published online: 16 May 2009

(C) Springer-Verlag and AWI 2009

\begin{abstract}
Mysid shrimps are an important trophic link in the food web of the Baltic Sea. In 2002 and 2003 we investigated species composition, distribution, life cycle and prey in the Bornholm Basin (central Baltic). Three species and one genus were identified: Mysis mixta, Neomysis integer, Mesopodopsis slabberi and Praunus sp. The dominant $M$. mixta and $N$. integer occurred in the whole study area but were more abundant in the peripheral, more shallow regions. Size frequency distribution indicated one generation for M. mixta and probably two for N. integer. Main prey of all size classes in both species was the cladoceran Bosmina coregoni maritima during summer and autumn. In spring and winter also copepods of the species Temora longicornis and Pseudocalanus acuspes were important prey items. Detritus and phytoplankton cells were of minor importance and many individuals had empty guts. Mysid shrimps in the deep basin might be advected from more shallow areas, as the abundance of all species was much lower than in coastal regions. The deep Bornholm Basin does not seem to be a favourable habitat, probably due to the inaccessibility of the oxygen deficient bottom layer. Under current hydrographic conditions mysids are probably not important predators of zooplankton and thus not competitors of planktivorous fish in the Bornholm Basin.
\end{abstract}

Keywords Mysis mixta $\cdot$ Neomysis integer $\cdot$ Praunus sp. · Mesopodopsis slabberi · Diet · Life cycle · Abundance . Central Baltic Sea $\cdot$ Bornholm Basin

Communicated by H.-D. Franke.

K. Barz $(\square) \cdot$ H.-J. Hirche

Alfred Wegener Institute for Polar and Marine Research, Am Alten Hafen 26, 27568 Bremerhaven, Germany

e-mail: kristina.barz@awi.de

\section{Introduction}

Mysid shrimps are widespread all over the world and occupy diverse habitats and water depths (Mauchline 1980). Several species are living in the Baltic Sea, where special hydrographic conditions may limit their distribution (Köhn 1992). The Baltic Sea is the largest enclosed brackish water system worldwide and is characterized by a series of deep basins separated by shallow sills. The salinity is one main factor causing regional differences. It decreases from west to east and from south to north and also forms vertical gradients in the deep basins. The Bornholm Basin (BB) in the central Baltic Sea has a strong stratification with a permanent halocline and a summer thermocline. Below the halocline decomposition processes cause anoxic conditions. The pycnoclines form a three-storeyed ecosystem of water masses with different thermal and haline combinations (Schulz 2006) which is inhabited by the organisms according to their physiological requirements. For example, the zooplankton community in summer is dominated by cladocerans above the thermocline and copepods below it (Schulz 2006). Various species-specific and ontogenetic intraspecific differences in the vertical distribution were found (Barz and Hirche 2005; Renz and Hirche 2006; Schulz 2006; Schulz and Hirche 2007). As many species reach the limits of their distributional and reproductive ranges at different isohalines, species composition is changing all over the Baltic along this gradient.

Salinity in combination with temperature, depth and oxygen concentration at the bottom is also limiting the distribution of mysids (e.g. Salemaa et al. 1986). Hence, only few of the species occurring in the Baltic are distributed eastwards of the Arkona Basin (Köhn 1992). Mysid shrimps are an important element of the food web in the Baltic Sea (e.g. Arndt and Jansen 1986; Rudstam and 
Hansson 1990). Many species are omnivorous and using pelagic and benthic food they form a link between these environments (Mauchline 1980). Thus Neomysis integer forms large swarms in the southern Baltic and feeds mainly on zooplankton (Jansen et al. 1980; Arndt and Jansen 1986). Mysis mixta is one of the major zooplanktivores in coastal areas of the northern Baltic Proper and may consume $20-50 \%$ of the zooplankton production annually (Rudstam et al. 1986). This makes mysids important competitors of planktivorous adult and larval fish (Rudstam and Hansson 1990). Mysids feed also on fish eggs and larvae and may therefore have an additional effect on the fish stocks (Torniainen and Lehtiniemi 2008). In turn, they serve as an essential food source, for example herring (Möllmann et al. 2004).

The BB is the spawning ground for the commercially important fish species cod and sprat (Köster et al. 2001, 2005). Together with medusae (Barz and Hirche 2005; Barz et al. 2006) and ctenophores (Haslob et al. 2007) mysids are the only abundant invertebrate predators in this region and may have a significant influence on the populations of fish. Previous studies on mysids in the Baltic were mostly located in the northern area (reviewed by Rudstam and Hansson 1990; Viherluoto et al. 2000). For the BB only Salemaa et al. (1990) and Margonski and Maciejewska (1999) gave an overview on occurrence and abundance. Our study within German GLOBEC provided the opportunity to analyse species composition and their spatial and seasonal distribution on a narrow station grid in the BB. Analysis of the food spectrum of different size classes of dominant species should provide insight into the trophic role of mysid shrimps in the BB and potential competition with fish.

\section{Materials and methods}

Sampling location, dates and hydrography

The study was carried out in the BB, which is one of the deep basins in the central Baltic Sea (Fig. 1). Samples were taken during nine cruises from April 2002 to March 2003 on a station grid of 52 stations ( $\sim 31-95 \mathrm{~m}$ depth). Salinity, temperature and dissolved oxygen were recorded on every station with a standard CTD probe.

\section{Abundance and distribution}

Mysid shrimps were collected from a Bongo net $(0.6 \mathrm{~m}$ diameter, $500 \mu \mathrm{m}$ mesh size) towed in double-oblique hauls integrating the whole water column from surface to $\sim 2 \mathrm{~m}$ above the bottom. Sampling was independent of time and daylight. Depending on weather conditions not all stations

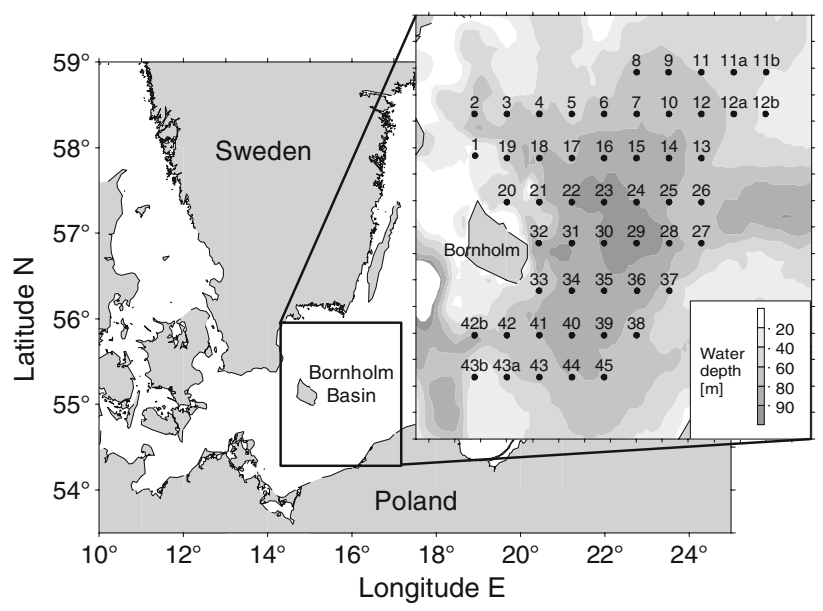

Fig. 1 Study area in the Baltic Sea with station grid and water depth (m)

were sampled on every cruise. The samples were preserved in a $4 \%$ borax-buffered formalin-seawater solution. In the laboratory the mysids were counted and identified to genus or species level. Abundance was calculated for all cruises in 2002 and 2003. Only for the cruise in early July no data on abundance were available. Spatial distribution of M. mixta and $N$. integer was plotted for end July, August and October 2002 and January 2003. Samples with high abundance were divided with a plankton splitter until the subsample contained a minimum of 300 individuals.

In July and August 2002 additional samples with an IKMT (Isaacs-Kidd Mid-Water Trawl, $6 \mathrm{~m}^{2}$ opening, $1,000 \mu \mathrm{m}$ mesh size) were taken for comparison with the catch efficiency of the Bongo net. A two-way ANOVA (Sokal and Rohlf 1981) and a matched pairs test were performed to analyse differences between the two net types. The volume of filtered water in both net types was measured with a flowmeter.

\section{Body size}

Mysid shrimps for body size measurements were collected from preserved Bongo net samples. In March 2003 not enough M. mixta for adequate size analyses were available. $N$. integer was less abundant, especially during the spring and summer cruises. Therefore, size analyses were not performed in July and August 2002. Total length (TL) was measured from the apex of the rostrum to the posterior end of the telson. All individuals were measured under a stereomicroscope to the nearest millimetre below.

Prey composition

Mysid shrimps for stomach content analyses were collected from preserved Bongo net samples. In March 2003 not enough animals of M. mixta for adequate prey analyses 
were available. Due to low abundance of $N$. integer prey analyses were performed only in June 2002 and from October 2002 to March 2003. After dissection with a fine scalpel, the separated stomach and gut were transferred to an object slide in a glycerine-water solution (1:1). Under a dissection microscope, the stomachs were opened with fine dissection needles and prey fragments separated. For better comparison with prey data from Viherluoto et al. (2000) and Lehtiniemi and Nordström (2008), M. mixta and $N$. integer were grouped into four size classes $(3-6,7-12$, 13-17, 18-21 mm).

Main focus of prey analyses was on mesozooplankton species. For their easier identification in the guts, a digital picture catalogue with fragments (mandibles, antennae, carapaces, characteristic body parts) of potential food items was established. By comparing the undigested fragments from the guts with pictures of potential prey, it was mostly possible to identify the gut content to species level. Thereby only the characteristic parts were used for identification and counting, e.g. two mandibles for one copepod and one pair of antennae for one Bosmina coregoni maritima. However, some mandibles or carapace fragments could not be assigned to prey species and were counted and pooled as unidentified objects. The amount $(\%)$ of guts containing only or additional material composed of detritus, sand and/or phytoplankton cells was also recorded.

\section{Results}

\section{Hydrography}

The hydrography of the central Baltic is characterized by stratification. From July to September 2002, a thermocline was found between 15 and $25 \mathrm{~m}$, separating the surface layer from the colder $\left(5-6^{\circ} \mathrm{C}\right)$ intermediate water layer. Temperature in the surface layer increased from $16^{\circ} \mathrm{C}$ in the beginning of July to the maximum summer temperature of $20.8^{\circ} \mathrm{C}$ in August. In November the surface water had cooled down to $9^{\circ} \mathrm{C}$ and merged with the intermediate water. Salinity was rather constant between the surface and the halocline (7) and increased beneath the halocline up to 15.5. Oxygen concentration decreased rapidly below the halocline to values $<2 \mathrm{ml}^{-1}$. Profiles of temperature, salinity and oxygen during our sampling period are published, e.g. in Feistel et al. (2003), Barz and Hirche (2005), Schulz (2006) and Mohrholz et al. (2006).

In late summer 2002, two exceptionally warm inflow events were observed in the BB. One appeared in the BB mainly in September 2002 (Feistel et al. 2003) and was distributed in the entire BB between 50 and $70 \mathrm{~m}$ by November (Mohrholz et al. 2006). An autumn inflow reached the BB in November 2002 and was detected in $80-90 \mathrm{~m}$. The temperature maxima of both inflows were measured in the BB during our cruises in October and November 2002 (Feistel et al. 2003).

Species composition, seasonal development, abundance and distribution

During the study period three species and one genus of mysid shrimps were identified in the BB: Mysis mixta, Neomysis integer, Mesopodopsis slabberi and Praunus sp.

$M$. mixta and $N$. integer occurred during the whole study period, whereas the other species appeared only sporadically (Fig. 2). From April to October 2002, M. mixta was the most abundant species. Its maximum abundance was reached in October $\left(7.5 \pm 20.5\right.$ ind. $\left.100 \mathrm{~m}^{-3}\right)$ and decreased strongly afterwards. $N$. integer showed the same seasonality with lower values until October (max. $1.9 \pm 4.9$ ind. $100 \mathrm{~m}^{-3}$ ) but was the most abundant species in November 2002 and January 2003 (Fig. 2). Praunus sp. was observed in April and July 2002 and January 2003 (sts. 45, 17 and 19, respectively) in low values (max. 0.5 ind. $\mathrm{m}^{-2}$ ). Some specimens of M. slabberi appeared in November 2002 on sta. $18\left(0.3\right.$ ind. $\left.\mathrm{m}^{-2}\right)$ and were still found in January 2003 (sts. 13, 18, 30; max. 0.9 ind. $\mathrm{m}^{-2}$ ). In March 2003 it was not longer detected.

On single stations, the abundance of M. mixta was highest in August and October (Fig. 3). In July they were found nearly in the entire basin with a tendency towards Bornholm Island, whereas in August and October they were mainly located at more shallow stations $(31-65 \mathrm{~m})$ in the north-eastern and the southern peripheral regions of the study area (Fig. 3). Maximum abundance was found in October on st. 44 (57.1 ind. $\left.\mathrm{m}^{-2}\right) . N$. integer was caught in the whole basin with higher numbers in the southern area in August and October. In January 2003, N. integer was mainly distributed off Bornholm Island (Fig. 3). Maximum abundance was found in October and January ( 7 ind. $\mathrm{m}^{-2}$ ) on sts. 43a and 19, respectively. In April and June 2002 and March 2003 all species were low in numbers and no distribution patterns were recognized.

M. mixta was used to compare the Bongo and IKMT catch efficiency, as it was the most abundant species in July and August 2002 when both nets were deployed. In July and August the Bongo net filtered an average water volume of $231.8 \pm 87.8$ and $204.0 \pm 94.5 \mathrm{~m}^{3}$, respectively, whereas the volume filtered by IKMT was $6,174.8 \pm$ $1,907.2 \mathrm{~m}^{3}$ and 5,308.7 $\pm 2,444.8 \mathrm{~m}^{3}$, respectively. In both months 16 stations were used for comparison. A two-way ANOVA showed neither an effect of the gear $(P=0.7494)$, nor of the cruise date $(P=0.8186)$ on the abundance of caught $M$. mixta. This result was confirmed by a matched pairs test when using all stations $(P=0.1336)$ and only stations with mysids $(P=0.1350)$. The values from the IKMT 
Fig. 2 Mean abundance (ind. $100 \mathrm{~m}^{-3}$ ) and standard deviation of all species during the study period ( $n d$ no data)
Fig. 3 Spatial distribution (ind. $\mathrm{m}^{-2}$ ) of Mysis mixta and Neomysis integer in July, August and October 2002 and January 2003
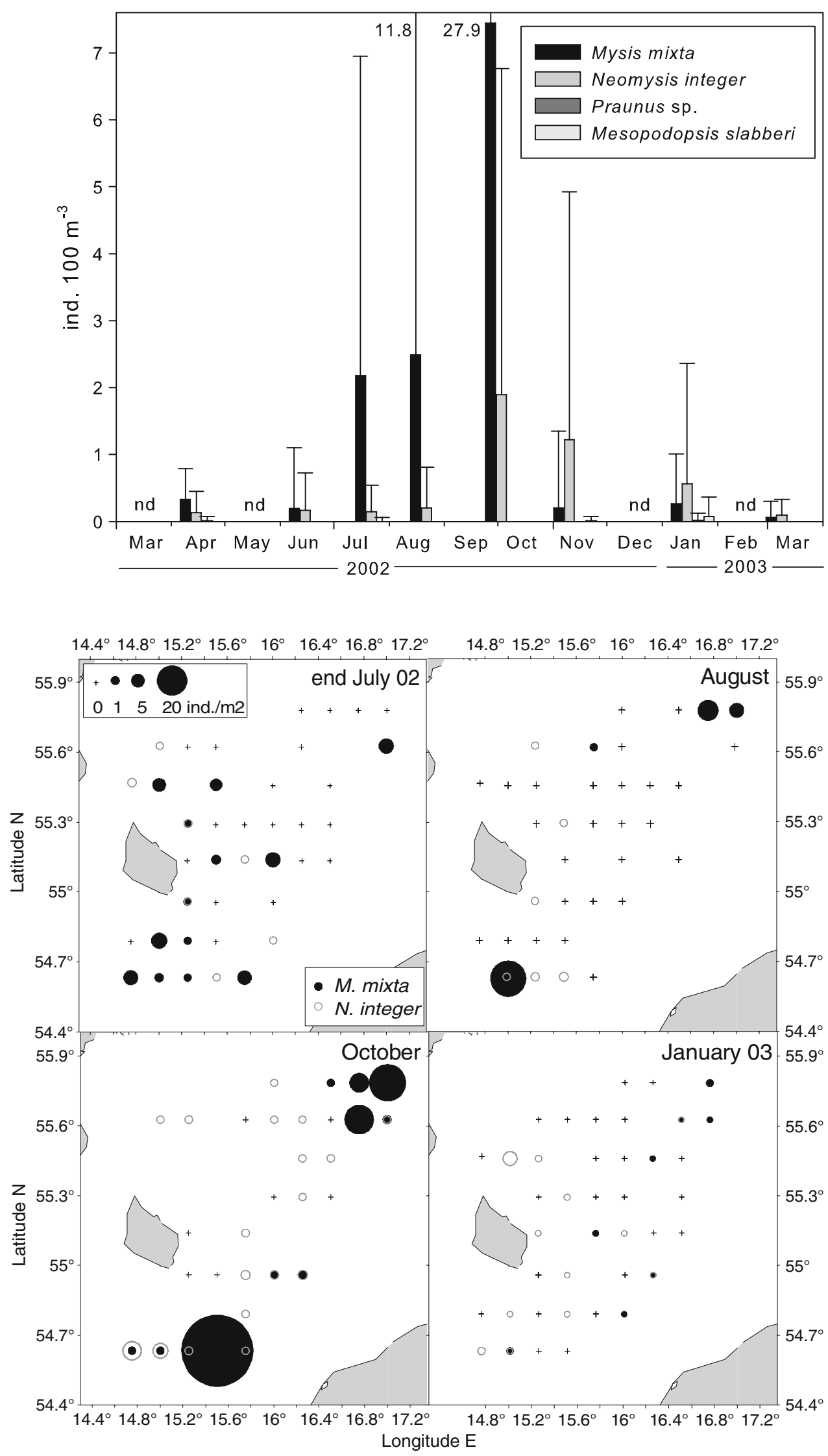


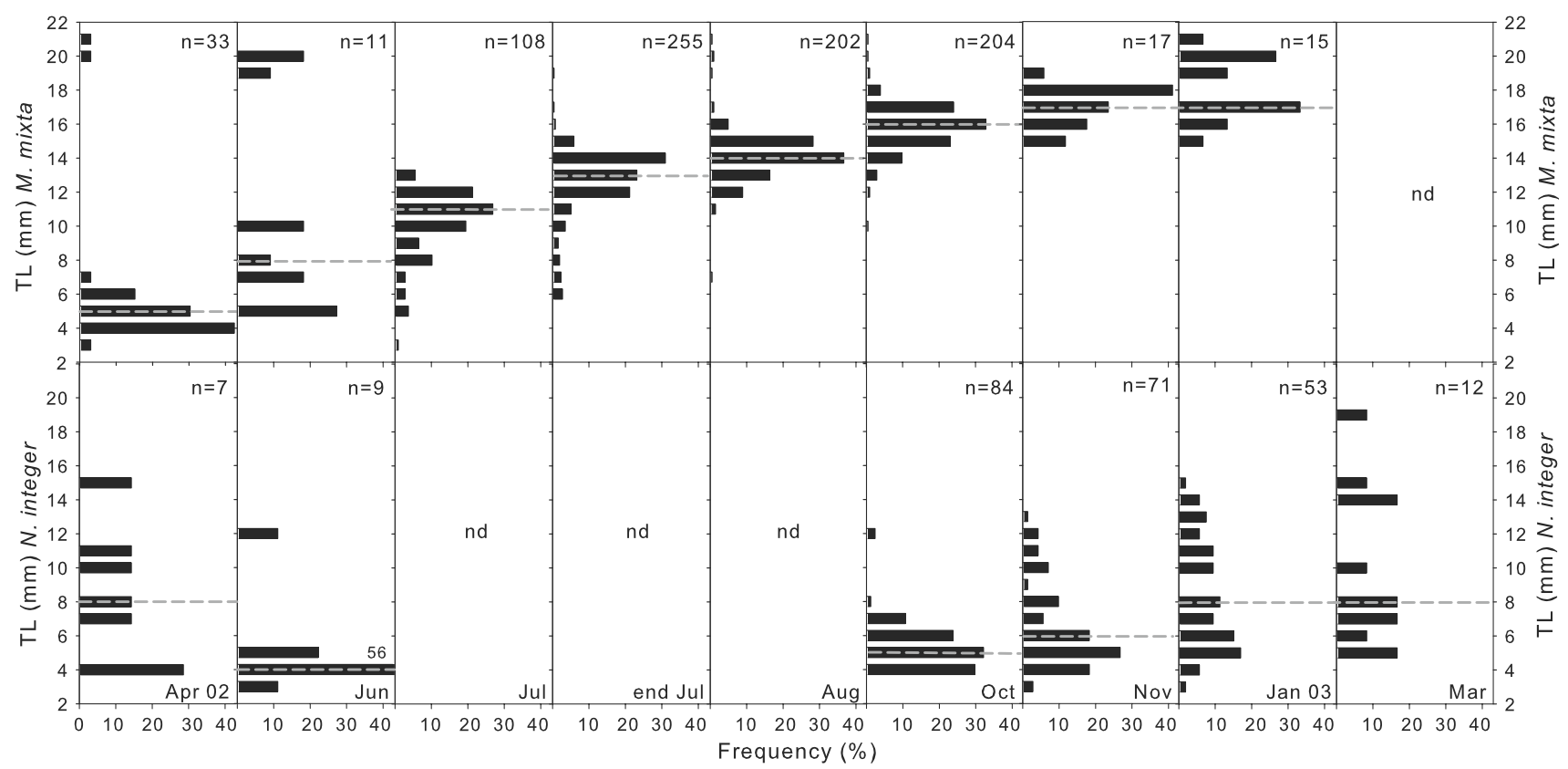

Fig. 4 Size (total length in mm) composition (\%) of the populations of Mysis mixta and Neomysis integer during the study period. $T L$ total length, $n$ number of individuals measured, $n d$ no data, grey line median

confirmed the higher abundance of M. mixta in the peripheral regions of the study area as found also in the Bongo net samples. The catch efficiency of the IKMT was expected to be higher than that of the Bongo due to the higher amount of filtered water which should reduce the influence of patchy distribution of mysids. However, the statistical analyses showed no difference between the two net types, probably caused by the high variability between stations.

\section{Size distribution}

The size of M. mixta varied between 3 and $21 \mathrm{~mm}$ (Fig. 4). The consistently increasing median, from 5 to $17 \mathrm{~mm}$ between April and November 2002, clearly documents the growth of the population. In January 2003, the median was still $17 \mathrm{~mm}$ but there was a group of some specimens larger than in November (Fig. 4).

The size of Neomysis integer ranged from 3 to $19 \mathrm{~mm}$. In April and June only few animals of variable size were measured and the smallest size class $(3-6 \mathrm{~mm})$ prevailed. Due to the low abundance, no size data are available for July and August. In October 2002, the median size was $5 \mathrm{~mm}$ and increased up to $8 \mathrm{~mm}$ in January 2003 (Fig. 4). In March 2003, the median was still $8 \mathrm{~mm}$ and the maximum size of $19 \mathrm{~mm}$ was reached. During the whole time, the smallest size group of 3-6 mm was found.

The median of body size of M. slabberi was $7 \mathrm{~mm}$ in January 2003. Due to rare occurrence only single individuals of Praunus sp. were measured (April 2002: $10 \mathrm{~mm}$, January 2003: 16 and $19 \mathrm{~mm}$ ).
Prey composition

Up to 36 identified prey organisms were found in the guts of individuals of $M$. mixta, but also many guts were empty (Table 1). Unidentified objects were found in almost every month and in all size classes analysed, but prevailed only in a few cases. The cladoceran Bosmina coregoni maritima and the copepod Temora longicornis were eaten by $M$. mixta and $N$. integer during the whole study period. From end of July to October 2002, B. coregoni maritima was the main prey item of $M$. mixta. In October also $N$. integer fed mostly on this species which can be easily identified by its typical first antennae. In spring, late autumn and winter, the preferred prey items of $M$. mixta were $T$. longicornis, Pseudocalanus acuspes or B. coregoni maritima, whereas $N$. integer fed on T. longicornis or P. acuspes but less on Bosmina. Further prey items of both species were the cladoceran Podon spp. and the copepod Centropages hamatus. The amount of detritus, sand and/or phytoplankton in the guts of both species was higher during early spring and winter (April 2002 and January-March 2003).

Differences in the prey composition in relation to size were hard to see. However, little differences were recognized for the smallest individuals. Almost all maximum values of empty guts were found in the smallest size group of both species (Table 1). The gut content of the smallest M. mixta individuals was less diverse than in the larger ones. Only 10 of 24 smallest M. mixta contained food in their guts. Detritus, sand and/or phytoplankton were of higher importance than in most other size groups. In contrast, for $N$. integer the ratios of 
Table 1 Composition of gut contents (\%) of different size classes of (a) Mysis mixta and (b) Neomysis integer

\begin{tabular}{|c|c|c|c|c|c|c|c|c|c|c|c|}
\hline Month & $\begin{array}{l}\text { Size class } \\
\text { TL (mm) }\end{array}$ & $n$ & $\begin{array}{l}\text { Empty } \\
N(\%)\end{array}$ & $\begin{array}{l}\text { Ident. prey } \\
\text { organisms }\end{array}$ & $\begin{array}{l}\text { B. coregoni } \\
\text { maritima }\end{array}$ & $\begin{array}{l}\text { Podon } \\
\text { sp. }\end{array}$ & P. acuspes & T. longicornis & C. hamatus & $\begin{array}{l}\text { Unident. } \\
\text { objects }\end{array}$ & $\begin{array}{l}\text { Detritus, } \\
\text { sand, phyto } \\
\text { (\% of guts) }\end{array}$ \\
\hline
\end{tabular}

(a)

\begin{tabular}{|c|c|c|c|c|c|c|c|c|c|c|c|}
\hline \multirow[t]{2}{*}{ April 2002} & $3-6$ & 13 & $7(54)$ & 1 & 100.0 & 0.0 & 0.0 & 0.0 & 0.0 & 0.0 & 38.5 \\
\hline & $18-21$ & 2 & $2(100)$ & 0 & 0.0 & 0.0 & 0.0 & 0.0 & 0.0 & 0.0 & 0.0 \\
\hline \multirow[t]{3}{*}{ June } & $3-6$ & 3 & $1(33)$ & 5 & 0.0 & 0.0 & 0.0 & 100.0 & 0.0 & 0.0 & 0.0 \\
\hline & $7-12$ & 5 & $1(20)$ & 8 & 22.2 & 0.0 & 0.0 & 55.6 & 11.1 & 11.1 & 20.0 \\
\hline & $18-21$ & 3 & $0(0)$ & 38 & 7.7 & 2.6 & 2.6 & 84.6 & 0.0 & 2.6 & 0.0 \\
\hline \multirow[t]{3}{*}{ July } & $3-6$ & 8 & $6(75)$ & 0 & 0.0 & 0.0 & 0.0 & 0.0 & 0.0 & 100 & 12.5 \\
\hline & $7-12$ & 17 & $1(6)$ & 82 & 8.0 & 2.3 & 9.2 & 63.2 & 11.5 & 5.7 & 0.0 \\
\hline & $13-17$ & 3 & $0(0)$ & 18 & 5.6 & 0.0 & 0.0 & 72.2 & 22.2 & 0.0 & 0.0 \\
\hline \multirow[t]{2}{*}{ End July } & $7-12$ & 13 & $2(15)$ & 103 & 85.6 & 11.5 & 1.9 & 0.0 & 0.0 & 1.0 & 0.0 \\
\hline & $13-17$ & 32 & $5(16)$ & 325 & 75.2 & 20.0 & 0.3 & 1.8 & 1.2 & 1.5 & 3.1 \\
\hline \multirow[t]{3}{*}{ August } & $7-12$ & 2 & $0(0)$ & 21 & 65.2 & 0.0 & 26.1 & 0.0 & 0.0 & 8.7 & 0.0 \\
\hline & $13-17$ & 39 & $1(3)$ & 542 & 88.0 & 5.1 & 3.3 & 2.2 & 0.0 & 1.5 & 12.8 \\
\hline & $18-21$ & 2 & $0(0)$ & 20 & 95.0 & 0.0 & 5.0 & 0.0 & 0.0 & 0.0 & 0.0 \\
\hline \multirow[t]{2}{*}{ October } & $13-17$ & 45 & $0(0)$ & 415 & 65.8 & 15.9 & 1.9 & 14.0 & 1.0 & 1.4 & 6.7 \\
\hline & $18-21$ & 6 & $1(17)$ & 51 & 84.3 & 11.8 & 0.0 & 2.0 & 2.0 & 0.0 & 0.0 \\
\hline \multirow[t]{2}{*}{ November } & $13-17$ & 3 & $0(0)$ & 25 & 8.0 & 4.0 & 24.0 & 64.0 & 0.0 & 0.0 & 0.0 \\
\hline & $18-21$ & 7 & $0(0)$ & 77 & 11.5 & 0.0 & 12.8 & 64.1 & 10.3 & 1.3 & 0.0 \\
\hline \multirow[t]{2}{*}{ January 2003} & $13-17$ & 7 & $0(0)$ & 28 & 62.1 & 3.4 & 10.3 & 20.7 & 0.0 & 3.4 & 42.9 \\
\hline & $18-21$ & 6 & $1(17)$ & 31 & 12.9 & 0.0 & 38.7 & 48.4 & 0.0 & 0.0 & 33.3 \\
\hline \multicolumn{12}{|l|}{ (b) } \\
\hline \multirow[t]{2}{*}{ June 2002} & $3-6$ & 8 & $8(100)$ & 0 & 0.0 & 0.0 & 0.0 & 0.0 & 0.0 & 0.0 & 0.0 \\
\hline & $7-12$ & 1 & $0(0)$ & 2 & 0.0 & 0.0 & 0.0 & 100.0 & 0.0 & 0.0 & 0.0 \\
\hline \multirow[t]{2}{*}{ October } & $3-6$ & 28 & $5(18)$ & 49 & 74.1 & 9.3 & 0.0 & 7.4 & 0.0 & 9.3 & 14.3 \\
\hline & $7-12$ & 12 & $0(0)$ & 60 & 90.2 & 3.3 & 1.6 & 3.3 & 0.0 & 1.6 & 8.3 \\
\hline \multirow[t]{2}{*}{ November } & $3-6$ & 13 & $3(23)$ & 28 & 3.2 & 0.0 & 6.5 & 67.7 & 12.9 & 9.7 & 0.0 \\
\hline & $7-12$ & 20 & $2(10)$ & 117 & 8.3 & 0.0 & 24.8 & 59.5 & 4.1 & 3.3 & 15.0 \\
\hline \multirow[t]{3}{*}{ January 2003} & $3-6$ & 9 & $8(89)$ & 3 & 0.0 & 0.0 & 33.3 & 66.7 & 0.0 & 0.0 & 0.0 \\
\hline & $7-12$ & 14 & $6(43)$ & 17 & 0.0 & 15.0 & 40.0 & 30.0 & 0.0 & 15.0 & 21.4 \\
\hline & $13-17$ & 8 & $1(13)$ & 23 & 0.0 & 0.0 & 43.5 & 52.2 & 4.3 & 0.0 & 12.5 \\
\hline \multirow[t]{3}{*}{ March } & $3-6$ & 3 & $1(33)$ & 1 & 0.0 & 0.0 & 0.0 & 50.0 & 0.0 & 50.0 & 33.3 \\
\hline & $7-12$ & 5 & $2(40)$ & 1 & 0.0 & 0.0 & 25.0 & 0.0 & 0.0 & 75.0 & 20.0 \\
\hline & $13-17$ & 3 & $0(0)$ & 8 & 12.5 & 0.0 & 37.5 & 50.0 & 0.0 & 0.0 & 0.0 \\
\hline
\end{tabular}

TL: total length; $n$ : number of individuals analysed; $N(\%)$ : portion of empty guts in number and percentage; ident.: identified; $B$. coregoni maritima: Bosmina coregoni maritima; P. acuspes: Pseudocalanus acuspes; T. longicornis: Temora longicornis; C. hamatus: Centropages hamatus; unident.: unidentified; detritus, sand, phyto: \% of guts containing parts or all of these objects; phyto: phytoplankton cells

different prey species in the guts of different size groups of the same month were similar.

\section{Discussion}

Species composition and distribution

Mysis mixta, Neomysis integer and Praunus spp. are common mysids of the Baltic Sea (Köhn 1992). Other species described for the northern Baltic like members of the recently revised Mysis relicta group (Audzijonyte and Väinölä 2005), and the Pontocaspian invader Hemimysis anomala (Janas and Wysocki 2005), were not detected in our samples. The fourth species observed in our study, Mesopodopsis slabberi, is common westwards of the Arkona Basin, where it may occur in high numbers in shallow waters (Köhn 1992; Wittmann 1992). Although Köhn (1992) suggested that mysids are rarely advected by currents, we take the possibility into consideration that two 
exceptionally warm inflow events may have transported some individuals of $M$. slabberi to the more easterly BB. The first inflow appeared in the BB in September 2002 (Feistel et al. 2003) turned right and spread along the western and southern rim of the basin (Mohrholz et al. 2006). By November it was distributed over the entire BB between 50 and $70 \mathrm{~m}$ (Mohrholz et al. 2006) when the first individuals of $M$. slabberi were caught. An autumn inflow reached the BB by November 2002 and may also have advected this unusual species, which was present until January 2003 before it disappeared. An effect on the distribution of the other species was not assumed as they have been found at least in low numbers in the entire basin before these inflows occurred.

Our sampling was independent from daytime and daylight, but always integrating the whole water column. Hence, vertical migration within the water column should not have affected abundance estimations. However, as previous studies, we did not sample specimens migrating between the seafloor and the near-bottom layer. On the other hand, the anoxic bottom layer of the deep BB probably is not inhabited by mysids anyway.

M. mixta was the most abundant species from April to October 2002. This is in accordance with Margonski and Maciejewska (1999), who worked in the same area from 1993 to 1996; however, not during winter. Its declining abundance during winter concurs with observations in the northern Baltic (Rudstam et al. 1986). M. mixta is described as a pelagic species inhabiting deeper waters. There it lives nectobenthic, is in bottom contact during daytime and performs diurnal vertical migrations (Rudstam et al. 1989; Köhn 1992; Viherluoto 2001; Kotta and Kotta 2001). $N$. integer, Praunus spp. and M. slabberi, in contrast, live in shallow waters of the littoral zone according to Jansen et al. (1980), Köhn (1992) and Viherluoto (2001). In northern Baltic coastal waters, $M$. mixta and $N$. integer reached maximum abundances of 314 ind. $\mathrm{m}^{-2}$ and 24 ind. $\mathrm{m}^{-2}$, respectively (Rudstam et al. 1986). N. integer in the shallow water $(<1 \mathrm{~m})$ of the Darss-Zingst Bodden chain reached even 554 ind. $\mathrm{m}^{-2}$ (Jansen et al. 1980). In our study highest abundance of $M$. mixta was found on the more shallow stations in the north-eastern and the southern peripheral regions in August (max. 25 ind. $\mathrm{m}^{-2}$ ) and October (max. 57 ind. $\mathrm{m}^{-2}$ ), N. integer reached abundance not higher than 7 ind. $\mathrm{m}^{-2}$ in the peripheral region. Thus abundance was much lower than the maxima reported above, but slightly higher than in previous studies by Salemaa et al. (1990) and Margonski and Maciejewska (1999) which found 1-20 M. mixta ind. $\mathrm{m}^{-2}$ near Bornholm Island and in the northeastern and southern area. Both authors proposed the absence of these two mysid species from the deep BB. Salemaa et al. $(1986,1990)$ related these findings to the oxygen deficiency in the deep layers. In contrast, we found both species in low numbers distributed all over the basin, although oxygen deficiency was still acute in 2002 (Feistel et al. 2003; Mohrholz et al. 2006) and the deep BB was not a proper habitat for M. mixta and $N$. integer. According to Salemaa et al. (1990), specimens found in this area might be advected from populations living in more favourable areas. They also suggested the existence of populations not dependent on the benthic habitat to avoid the oxygen deficiency.

Life cycle

The size frequency distribution of $M$. mixta suggests an annual life cycle as in the northern Baltic Sea, where juveniles are released in early spring, grow through the summer when food is abundant and mature in winter (Rudstam et al. 1986; Salemaa et al. 1986; Rudstam and Hansson 1990; Köhn 1992). The two size groups found in April probably represent females $(18-21 \mathrm{~mm})$ from the foregoing year which recently had released their offspring (3-6 mm).

For $N$. integer two generations per year were reported for the Baltic Sea (Kinne 1955; Jansen et al. 1980; Rudstam et al. 1986). Adults of the winter generation reproduce in spring. Their recruits form the summer generation, which is growing fast and matures in July/August at a smaller size ( $\sim 10 \mathrm{~mm}$ ) than the over-wintering generation. The scarcity of size data in our study does not allow to completely reconstruct the life cycle of this species in the central Baltic. Adults of the winter generation dominate in April 2002. Unfortunately, size data on the summer generation are completely missing. However, the size distribution in October clearly shows the newly, probably by the summer generation, released brood, which would represent the winter generation. The occurrence of small individuals until January 2003 indicates a successive release of brood through the summer as also found by Rudstam et al. (1986). The source regions of $N$. integer in the study area are probably the coastal regions from where it has been advected. The size distribution indicates that small individuals might be transported to deeper regions regularly and in higher numbers than larger individuals, eventually due to different ontogenetic vertical distribution and/or lower swimming efficiency.

\section{Prey composition}

Based on prey composition, mysid shrimps are classified as omnivorous and capable of utilizing a wide variety of food sources (e.g. Rudstam et al. 1989; Viherluoto et al. 2000; Lehtiniemi and Nordström 2008). M. mixta (Hansson et al. 1990; Mohammadian et al. 1997; Viherluoto 2001) and $N$. integer (Köhn 1992) showed a preference towards carnivory. This is confirmed in our study where mainly 
mesozooplankton species together with some detritus, sand and phytoplankton cells were found in their guts. The food composition of all size classes of both species mainly reflected the seasonal changes in the zooplankton composition. Temora longicornis was the main prey item of M. mixta in June and early July 2002, when CIV-CVI stages of this species reached their maximum abundance (Schulz 2006; Schulz et al. 2008). During July, M. mixta switched to Bosmina coregoni maritima as main food source, although T. longicornis was still very numerous until August. $B$ coregoni maritima was highly abundant from July to October with mass occurrence in August (Schulz 2006; Schulz et al. 2008). Its high abundance in summer combined with low escape capability (Viitasalo et al. 2001) made $B$. coregoni maritima an easy prey for $M$. mixta and $N$. integer during this time. In the plankton, B. coregoni maritima is present, however, in small numbers all year round (Schulz 2006) and occurred sporadically in the guts also in winter and spring. From November on, when the Bosmina population decreased rapidly, copepods became again a more important food source. Both mysid species fed now mainly on relatively low abundant $T$. longicornis and on Pseudocalanus acuspes. The main prey items, B. coregoni maritima and $T$. longicornis, inhabit the upper $30 \mathrm{~m}$ and the shallower marginal regions of the BB (Hansen et al. 2006; Schulz 2006) and therefore indicate a feeding close to the surface. The vertical distribution of $P$. acuspes was changing during season (Renz and Hirche 2006). As during winter, larger stages were found deep dwelling as well as close to the surface, we cannot distinguish where mysids fed on this copepod species. Anyhow, $P$. acuspes became more attractive and/or accessible from November on. Interestingly, the two common Acartia species A. bifilosa and A. longiremis, which were also present in the central Baltic Sea all year round (Schulz 2006), were not found in the guts. Viherluoto and Viitasalo (2001) and Viitasalo et al. (2001) found negative selection for Acartia spp. by M. mixta in laboratory experiments, probably due to their high escape capability (Viitasalo and Rautio 1998; Viitasalo et al. 2001). In accordance with our results, copepods and cladocerans were described as the main prey items in former studies (Hansson et al. 1990; Rudstam et al. 1989) together with detritus and plant material (Rudstam et al. 1989; Lehtiniemi and Nordström 2008). An ontogenetic shift in food preference of $M$. mixta from sedimented phytoplankton to mesozooplankton described by Viherluoto et al. (2000), which these authors ascribed to inefficient handling of mesozooplankton by small mysids $(<7 \mathrm{~mm})$, was not absolutely confirmed here. In April and July but not in June 2002 the amount of detritus, sand and/or phytoplankton was higher in the smallest size group of M. mixta, but also mesozooplankton such as $B$. coregoni maritima and $T$. longicornis was eaten in small numbers. It seems that small individuals are indeed able to handle large prey in certain cases, but also many guts remained empty. For the actually littoral species $N$. integer Lehtiniemi and Nordström (2008) found no clear ontogenetic diet shifts, but benthic and planktonic material in the guts of all size classes. Besides some detritus and sand, mesozooplankton was the main food for all $N$. integer in our study. The absence of a clear ontogenetic diet shift in M. mixta and the lack of benthic prey in $N$. integer as well as the many empty guts in smallest individuals of both species make us speculate that oxygen deficiency on the bottom of the deep BB makes the feeding ground near the sediment inaccessible for all size groups investigated.

\section{Effects on fish stocks}

The BB is an important spawning ground for cod and sprat (Bagge et al. 1994; Köster et al. 2001, 2005). The larvae of both species (Groenkjaer and Wieland 1997; Voss et al. 2003; Dickmann et al. 2007) as well as the adults of sprat and herring (Möllmann et al. 2004) feed on copepods and on cladocerans and hence compete with the mysids for food in the BB. In addition, mysids feed on fish eggs and larvae and may therefore have an additional effect on the fish stocks (Torniainen and Lehtiniemi 2008). In turn, mysids may serve as an important food resource for some size classes of herring especially in winter and autumn (Möllmann et al. 2004). However, compared to coastal areas, e.g. in the northern Baltic (Rudstam et al. 1986) all mysid species had a low abundance in the $\mathrm{BB}$ which is probably due to the deep and oxygen deficient bottom layer. It seems that the Baltic mysids strongly depend on access to the sea floor, which due to oxygen conditions is only possible in the more shallow parts of the BB. Therefore, under current hydrographic conditions, they are not important in the trophodynamics of the deep BB. However, BB fish stocks like herring, which migrate for spawning to more shallow waters with higher abundance of mysids, may benefit from additional food supply, and suffer from competition for food and/or predation on eggs and larvae. We speculate that under better oxygenated conditions, mysid shrimps could also become an important component in the food web of the BB.

Acknowledgments This study would not have been possible without the support of many colleagues, students and crew members of RV Alkor, Heincke and A. v. Humboldt during several cruises. Special thanks to Ulrike Holtz, Sabine Lenk and Sabine Graf for their help in analysing specimens. We are further grateful to Asta Audzijonyte confirming the identification of small Mysis mixta specimens, Dr. habil Thomas Brey helping in statistical analyses and the anonymous reviewer for helpful comments on the manuscript. This research was funded by Bundesministerium für Bildung und Forschung (BMBF 03F0320D) in the framework of GLOBEC Germany. 


\section{References}

Arndt EA, Jansen W (1986) Neomysis integer (Leach) in the chain of boddens south of Darß/Zingst (western Baltic)—ecophysiology and population dynamics. Ophelia Suppl 4:1-5

Audzijonytė A, Väinölä R (2005) Diversity and distributions of circumpolar fresh- and brackish-water Mysis (Crustacea: Mysida): Descriptions of $M$. relicta Lovén, 1862, M. salemaai $\mathrm{n}$. sp., M. segerstralei n. sp. and M. diluviana n. sp., based on molecular and morphological characters. Hydrobiologia 544:89-141

Bagge O, Thurow F, Steffensen E, Bay J (1994) The Baltic cod. Dana 10:1-29

Barz K, Hirche H-J (2005) Seasonal development of scyphozoan medusae and the predatory impact of Aurelia aurita on the zooplankton community in the Bornholm Basin (central Baltic Sea). Mar Biol 147:465-476

Barz K, Hinrichsen H-H, Hirche H-J (2006) Scyphozoa in the Bornholm Basin (central Baltic Sea) - the role of advection. J Mar Syst 60:167-176

Dickmann M, Möllmann C, Voss R (2007) Feeding ecology of Central Baltic sprat Sprattus sprattus larvae in relation to zooplankton dynamics: implications for survival. Mar Ecol Prog Ser 342:277-289

Feistel R, Nausch G, Mohrholz V, Lysiak-Pastuszak E, Seifert T, Matthaus W, Kruger S, Hansen IS (2003) Warm waters of summer 2002 in the deep Baltic Proper. Oceanologia 45:571-592

Groenkjaer P, Wieland K (1997) Ontogenetic and environmental effects on vertical distribution of cod larvae in the Bornholm Basin, Baltic Sea. Mar Ecol Prog Ser 154:91-105

Hansen FC, Möllmann C, Schütz U, Neumann T (2006) Spatio-temporal distribution and production of calanoid copepods in the central Baltic Sea. J Plankton Res 28:39-54

Hansson S, Larsson U, Johansson S (1990) Selective predation by herring and mysids, and zooplankton community structure in a Baltic Sea coastal area. J Plankton Res 12:1099-1116

Haslob H, Clemmesen C, Schaber M, Hinrichsen H-H, Schmidt JO, Voss R, Kraus G, Köster FW (2007) Invading Mnemiopsis leidyi as a potential threat to Baltic fish. Mar Ecol Prog Ser 349:303-306

Janas U, Wysocki P (2005) Hemimysis anomala G.O. Sars 1907 (Crustacea, Mysidacea)_first record in the Gulf of Gdansk (Baltic Sea). Oceanologia 47:405-408

Jansen W, Arndt EA, Hahn W, Bittorf T, Wronna F, Raschewski U (1980) Untersuchungen zur Populationsentwicklung von Neomysis integer (Leach) in der Darß-Zingster Boddenkette. Wiss Z Wil-Pieck-Univ Rostock 4:95-97

Kinne O (1955) Neomysis vulgaris Thomson, eine autökologischbiologische Studie. Biologisches Zentralblatt 74:160-202

Köhn J (1992) Mysidacea of the Baltic - State of the art. In: Köhn J, Jones MB, Moffat A (eds) Taxonomy, biology and ecology of (Baltic) mysids (Mysidacea: Crustacea). Rostock University, Hiddensee, pp 5-24

Köster FW, Möllmann C, Neuenfeldt S, St. John MA, Plikshs M, Voss R (2001) Developing Baltic cod recruitment models. I. Resolving spatial and temporal dynamics of spawning stock and recruitment for cod, herring, and sprat. Can J Fish Aquat Sci 58:1516-1533

Köster FW, Möllmann C, Hinrichsen H-H, Wieland K, Tomkiewicz J, Kraus G, Voss R, Makarchouk A, MacKenzie BR, St. John MA, Schnack D, Rohlf N, Linkowski T, Beyer JE (2005) Baltic cod recruitment - the impact of climate variability on key processes. ICES J Mar Sci 62:1408-1425

Kotta I, Kotta J (2001) Vertical migrations of mysids in the Gulf of Riga. Proc Estonian Acad Sci Biol Ecol 50:248-255

Lehtiniemi M, Nordström H (2008) Feeding differences among common littoral mysids, Neomysis integer, Praunus flexuosus and $P$. inermis. Hydrobiologia 614:309-320
Margonski P, Maciejewska K (1999) The distribution, abundance and biomass of Mysis mixta and Neomysis integer (Crustacea: Mysidacea) in the open waters of the southern Baltic Sea. Bull Sea Fish Inst Gdynia 147:23-35

Mauchline J (1980) The biology of mysids and euphausiids. Adv Marine Biol 18:1-369

Mohammadian MA, Hansson S, De Stasio BT (1997) Are marine planktonic invertebrates food limited? The functional response of Mysis mixta (Crustacea, Mysidacea) in the Baltic Sea. Mar Ecol Prog Ser 150:113-119

Mohrholz V, Dutz J, Kraus G (2006) The impact of exceptionally warm summer inflow events on the environmental conditions in the Bornholm Basin. J Mar Syst 60:285-301

Möllmann C, Kornilovs G, Fetter M, Köster FW (2004) Feeding ecology central Baltic Sea herring and sprat. J Fish Biol 65:15631581

Renz J, Hirche H-J (2006) Life cycle of Pseudocalanus acuspes Giesbrecht (Copepoda, Calanoida) in the Central Baltic Sea: I. Seasonal and spatial distribution. Mar Biol 148:567-580

Rudstam LG, Hansson S (1990) On the ecology of Mysis mixta (Crustacea, Mysidacea) in a coastal area of the northern Baltic proper. Ann Zool Fennici 27:259-263

Rudstam LG, Hansson S, Larsson U (1986) Abundance, species composition and production of mysid shrimps in a coastal area of the northern Baltic Proper. Ophelia Suppl 4:225-238

Rudstam LG, Danielsson K, Hansson S, Johansson S (1989) Diel vertical migration and feeding patterns of Mysis mixta (Crustacea, Mysidacea) in the Baltic Sea. Mar Biol 101:43-52

Salemaa H, Tyystjärvi-Muuronen K, Aro E (1986) Life histories, distribution and abundance of Mysis mixta and Mysis relicta in the northern Baltic Sea. Ophelia Suppl 4:239-247

Salemaa H, Vuorinen I, Välipakka P (1990) The distribution and abundance of Mysis populations in the Baltic Sea. Ann Zool Fennici 27:253-257

Schulz J (2006) Spatial and temporal distribution patterns of zooplankton in the central Baltic Sea and methods to detect them. Dissertation, University Bremen, Germany, $196 \mathrm{pp}$

Schulz J, Hirche H-J (2007) Living below the halocline: strategies of deep-living species in the highly stratified brackish Bornholm Basin (central Baltic Basin). J Plankton Res 29:881-894

Schulz J, Tamm S, Moll A, Zabanski S (2008). GLOBEC-Germanyintegrated datasets, WDC-MARE Reports, 7, $28 \mathrm{pp}$, hdl:10013/ epic.32135, incl. CD-ROM (link to the image of CD-ROM. http:/ /hs.pangaea.de/WDC-MARE/wdc-mare_0007.iso)

Sokal RR, Rohlf FJ (1981) Biometry. W.H. Freeman, New York

Torniainen J, Lehtiniemi M (2008) Potential predation pressure of littoral mysids on herring (Clupea harengus membras L.) eggs and yolk-sac larvae. J Exp Mar Biol Ecol 367:247-252

Viherluoto M (2001) Food selection and feeding behaviour of Baltic Sea mysid shrimps. Dissertation, University Hesinki, Finland, $35 \mathrm{pp}$

Viherluoto M, Viitasalo M (2001) Temporal variability in functional responses and prey selectivity of the pelagic mysid, Mysis mixta, in natural prey assemblages. Mar Biol 138:575-583

Viherluoto M, Kuosa H, Flinkman J, Viitasalo M (2000) Food utilisation of pelagic mysids, Mysis mixta and M. relicta, during their growing season in the northern Baltic Sea. Mar Biol 136:553-559

Viitasalo M, Rautio M (1998) Zooplanktivory by Praunus flexuosus (Crustacea: Mysidacea): functional responses and prey selection in relation to prey escape responses. Mar Ecol Prog Ser 174:7787

Viitasalo M, Flinkman J, Viherluoto M (2001) Zooplanktivory in the Baltic Sea: a comparison of prey selectivity by Clupea harengus and Mysis mixta, with reference to prey escape reactions. Mar Ecol Prog Ser 216:191-200 
Voss R, Köster FW, Dickmann M (2003) Comparing the feeding habits of co-occurring sprat (Sprattus sprattus) and cod (Gadus morhua) larvae in the Bornholm Basin, Baltic Sea. Fish Res 63:97-111
Wittmann KJ (1992) Morphogeographic variations in the genus Mesopodopsis Czerniavsky with descriptions of three new species (Crustacea, Mysidacea). Hydrobiologia 241:71-89 